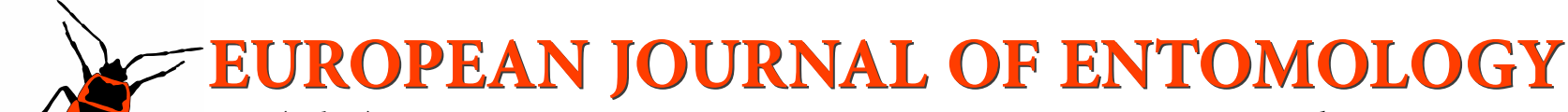 \\ ISSN (online): 1802-8829 \\ http://www.eje.cz \\ Eur. J. Entomol. 115: 684-696, 2018 \\ doi: 10.14411/eje.2018.067 \\ ORIGINAL ARTICLE
}

\section{The life cycles of Boyeria irene and Onychogomphus uncatus (Odonata: Aeshnidae, Gomphidae) in western Spain: A biometric study}

\author{
Tatiana VELASCO-VILLANUEVA ${ }^{1,2}$, Francisco $_{\text {CAMPOS }}{ }^{1}$, Ulf NORLING $^{3}$ and ManUel FERRERAS-ROMERO ${ }^{2}$ \\ ${ }^{1}$ Departamento de Ciencias Experimentales, Universidad Europea Miguel de Cervantes, Calle Padre Julio Chevalier, 2, \\ 47012 Valladolid, Spain; e-mails: tvelascovillanueva@gmail.com, fcampos@uemc.es \\ ${ }^{2}$ Departamento de Sistemas Físicos, Químicos y Naturales, Universidad Pablo de Olavide, 41013 Sevilla, Spain; \\ e-mail: mferrom@upo.es \\ ${ }^{3}$ Department of Urban Studies, Malmö University, SE-205 06 Malmö, Sweden; e-mails: ulf.norling@comhem.se, \\ ulf.norling@mau.se
}

\begin{abstract}
Key words. Odonata, Aeshnidae, Gomphidae, dragonfly, Boyeria irene, Onychogomphus uncatus, life cycle, permanent
\end{abstract} streams, larval sizes, seasonal regulation, voltinism, Spain

\begin{abstract}
Co-occurrence of species with similar trophic requirements, such as odonates, seems to depend both on them occupying different microhabitats and differing in their life-cycles. The life cycles of the dragonflies Boyeria irene and Onychogomphus uncatus were studied in two consecutive years, mainly by systematic sampling of larvae in seven permanent head courses that constitute the upper basin of the River Águeda, western Spain, in the central part of the ranges of these two species. The size ranges of the last five larval stadia of both species were established based on biometric data. The eggs of the egg-overwintering aeshnid hatched in late spring and early summer and for the gomphid hatching peaked in middle-late summer. Both species showed mixed voltinism with "cohort splitting". B. irene had a dominant three-year development (partivoltinism), with some developing in two years (semivoltinism). $O$. uncatus requires four, sometimes three years to complete development (all partivoltine). $B$. irene larvae spent the winter before emergence in the last three, maybe four stadia, as a "summer species". O. uncatus mainly behaved as a "spring species", most larvae spending the last winter in the final larval stadium.
\end{abstract}

\section{INTRODUCTION}

Co-occurrence of species with similar requirements is possible in habitats with seasonal pulses of high productivity (Larson, 1985); likewise, in cold, less productive habitats the co-occurrence of larvae of species of Anisoptera with long life-cycles seems to rely on both the utilization of different microhabitats and on differences in their lifecycles (Corbet, 1999).

Current knowledge of the life cycles of Odonata is biased towards more northern temperate areas and to some extent those with larvae that live in ponds. The Mediterranean area is thus interesting in bridging the gap to the subtropics. To determine the pattern of larval development in nature it is nearly always necessary to sample larvae at suitable intervals and determine the size-frequency distribution and, for the last few stadia, the stadium-frequency distribution. This knowledge is needed in order to understand how life-cycles have adapted to different regions and environments, and how seasonal regulation is achieved (Corbet, 1999). The present study presents such data for two lotic species in the Mediterranean area.
Gomphid dragonflies typically occur in streams and rivers, where larvae of the genus Onychogomphus Selys, 1854 live as burrowers, O. uncatus in sand, gravel and between stones (Suhling \& Müller, 1996). The aeshnid Boyeria irene (Fonscolombe, 1838) also develops in streams, but its larvae live as claspers on the bottoms of streams. Except in the early stadia they are dark and uniform in colour, and exhibit reflex immobilization (Robert, 1958; Corbet, 1999). Both B. irene and Onychogomphus uncatus (Charpentier, 1840) range from Central Europe to northern Africa, and some western Mediterranean islands (Askew, 2004; Boudot \& Dommanget, 2015; Boudot et al., 2015); but $O$. uncatus was last recorded on the borders of Switzerland and Germany more than twenty years ago, and $B$. irene persists only in one or two populations in Germany (Suhling \& Müller, 1996; Clausnitzer et al., 2010). In the broad sense both are restricted to the western Mediterranean (Ferreras-Romero, 1999; Boudot et al., 2009).

Information on the life cycles of $B$. irene and $O$. uncatus throughout their distributions is relatively scarce. In southern Spain B. irene is mainly a semivoltine "summer species" (sensu Corbet, 1954, 1964; i.e., the winter be- 


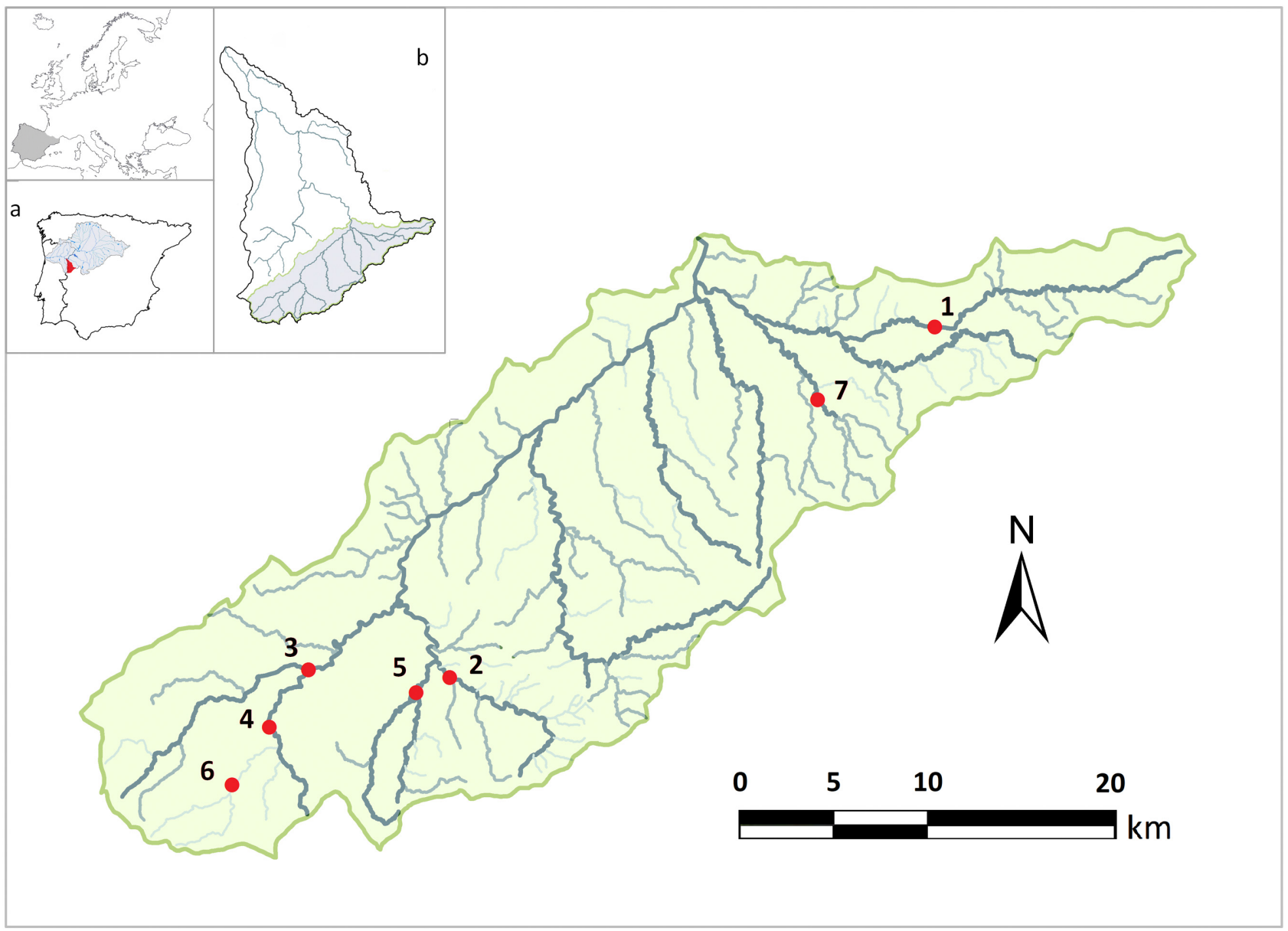

Fig. 1. Map of the upper basin of the River Águeda and its location in the River Águeda catchment (b) and Duero catchment (a) on the Iberian Peninsula. In red the location of the seven sites sampled in the study area: 1 - Agadón stream; 2 - Frío stream; 3 - river Águeda; 4 - Payo stream; 5 - Perosín stream; 6 - Rubioso stream; 7 - Vegas stream.

fore adult emergence was spent in several late stadia and emergence is late and asynchronous) and it overwinters for the first time as an egg (Ferreras-Romero, 1997). There is also interesting information about egg development, foraging and reproductive behaviour in southern France and NE Spain (Wenger, 1955, 1963; Jurzitza, 1967; Miller \& Miller, 1985).

On the other hand, O. uncatus lacks embryonic diapause and in the field (southern France) eggs hatch about four weeks after being laid (Schütte et al., 1998). In southern Spain this species has a protracted, flexible larval development, completed in two or three years, and mainly has summer species characteristics (Ferreras-Romero et al., 1999). In southern France O. uncatus is known to develop in three years (Shütte et al., 1998), and may appear both as a summer species (cf. above) and a spring species (sensu Corbet, 1954, 1964; the winter before emergence mainly spent in the last stadium, which results in an early and synchronous emergence). Suhling (1995) records both types of emergence patterns in two different populations about 2 km apart (Suhling \& Müller, 1996), probably explained by differences in temperature conditions.

Flexibility in larval development and facultative voltinism has opened the way for dragonflies to occupy cold, less productive habitats at the cost of a longer larval life, e.g. at higher latitudes and altitudes (Thompson, 1978; Norling, 1984; Corbet, 1999; Corbet et al., 2006). The main purpose of this study was to compare the patterns of larval growth and voltinism recorded for these two species on a cold high plateau on the Iberian Peninsula, with the results of previous studies done in the warm mountain ranges of southern Spain (Ferreras-Romero, 1997; Ferreras-Romero et al., 1999).

\section{MATERIAL AND METHODS}

The present study was carried out in the upper basin of the River Águeda (River Duero basin), in the Sistema Central Mountains, Salamanca province, western Spain (Fig. 1). This area covers $812 \mathrm{~km}^{2}$ (Confederación Hidrográfica del Duero, 2018) at an altitude mostly between 600 and $1400 \mathrm{~m}$ a.s.l., but reaching $1700 \mathrm{~m}$ a.s.l. in the western part of the upper river basin (Junta de Castilla y León, 2018). The climate is Mediterranean with an oceanic influence. The mean annual air temperature is $10^{\circ} \mathrm{C}$ and the annual rainfall varies between 550 and $1200 \mathrm{~mm}$, increasing southwesterly due to the Atlantic influence (Ramírez \& Reguera, 1995). The supramediterranean and mesomediterranean bioclimatic types (Rivas-Martínez, 1987) characterize this landscape. The arboreal vegetation is dominated by Pyrenean oak (Quercus pyrenaica) and holm oak (Quercus rotundifolia).

The study sites were permanent stretches of seven upland streams, about $745-900 \mathrm{~m}$ a.s.l., at roughly $40^{\circ} 20^{\prime} \mathrm{N}, 06^{\circ} 30^{\prime} \mathrm{W}$ 


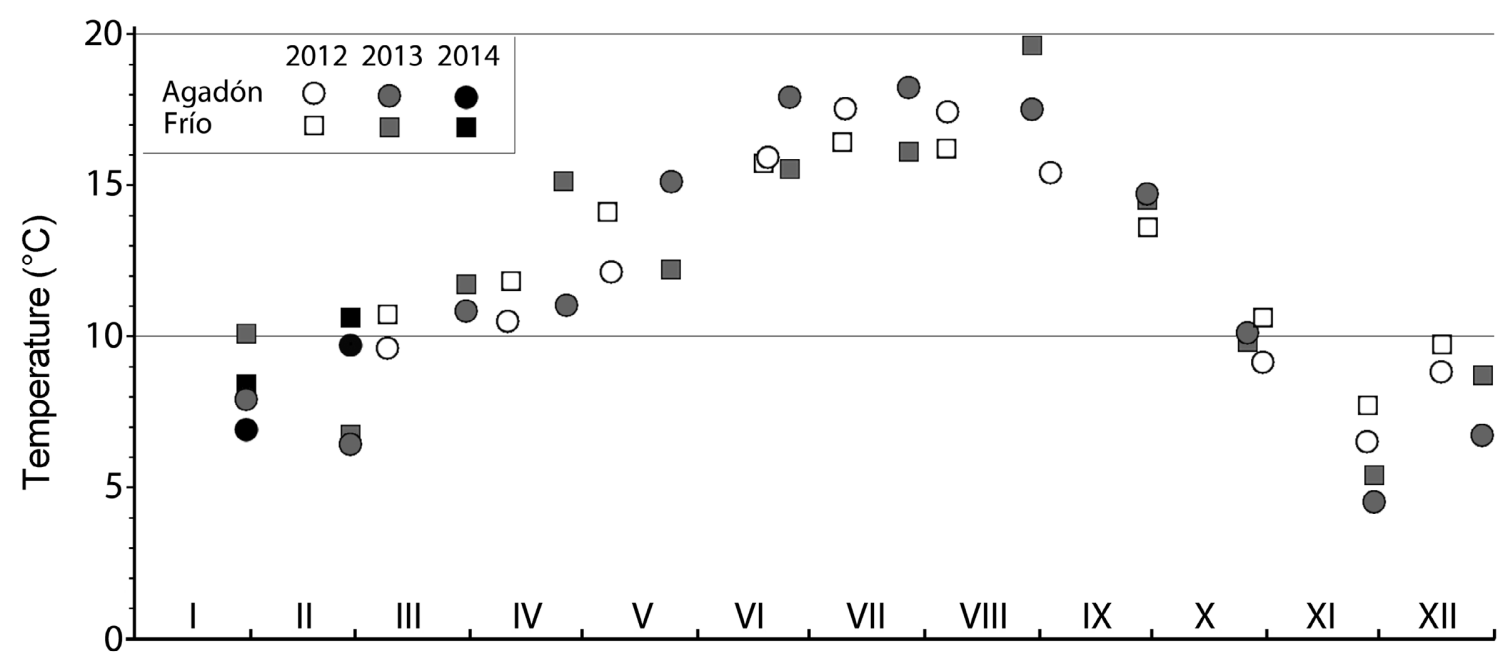

Months

Fig. 2. Monthly records, from March 2012 to February 2014, of the temperature of the water in Agadón and Frío streams.

(Table 1). In these watercourses, four other species of Odonata existed as stable populations: Calopteryx virgo (Linnaeus, 1758), Calopteryx xanthostoma (Charpentier, 1825), Pyrrhosoma nymphula (Sulzer, 1776), and Cordulegaster boltonii (Donovan, 1807) (Campos et al., 2013), but B. irene and O. uncatus were the most abundant in larval samples.

After some exploratory collections in 2011, larvae were collected monthly from March 2012 to February 2014, from the Frío and Agadón streams. The collections were usually made at the end of each month, using hand-nets with square mesh (one side of a square $=0.25 \mathrm{~mm}$ ) and the kick-sampling method (Sutherland, 2006); at each visit water temperature in both streams was recorded in situ to the nearest $0.1^{\circ} \mathrm{C}$ with a Crison Oxi 330 (Fig. 2). In five other streams (Table 1), larvae were collected four times within the same period (June and September 2012; January and April 2013) using the same sampling method. To obtain additional information about the larval growth season, exuviae of stadia previous to the final one found in the water were also collected and studied. Larvae and exuviae were preserved in the field in $70 \%$ ethanol. Sampling effort exerted in the Agadón and Frío streams (in each of them 24 samples were collected) was six times greater than in sampling each one of other five streams (only four samples from each of them).

The highest water temperatures recorded $\left({ }^{\circ} \mathrm{C}\right)$ in Frío stream were 19 (August 2013) and 16 (July and August 2012, July 2013) and the lowest 5 (November 2013). The highest water temperatures recorded $\left({ }^{\circ} \mathrm{C}\right)$ in Agadón stream were 18 (July 2013) and 17 (July and August 2012, June and August 2013) and the lowest 4 (November 2013).

In the laboratory, the head width (HW) of each larva and the length of the metathoracic (hind) wing sheaths (WSL), if present, were measured using a Nikon SMZ800 binocular microscope with an eyepiece micrometer (Ferreras-Romero, 1997); measurements were subsequently reduced to the nearest $0.1 \mathrm{~mm}$. The ratio $\mathrm{WSL} / \mathrm{HW}$ was also calculated to assist with stadium assignment (Tennessen, 2017). Also the HW of each exuvia collected in the water was recorded, although only an approximate measurement, since the head capsule is split during ecdysis. On the basis of these data each larva and every exuvia was either assigned to one of the last five larval stadia or designated a "smaller larva". Here we follow the common practice, in designating the final, penultimate and preceding stadia as F-0, F-1, F-2, etc. However, it should be borne in mind that the total number of stadia in Odonata is variable (Corbet, 1999, 2002).

The sex of each larva belonging to $B$. irene in one of the last five stadia was determined according to the presence (female) or absence (male) of gonapophyses on the ventral surface of the eighth and ninth abdominal segments. In the case of O. uncatus, male larvae in the final larval stadium were identified by the presence of subtle folds in the cuticle existing on the ventral side of the second abdominal segment.

Presence or absence of a thick coating of allochthonous particles on the body surface, especially on the ventral surface of the abdomens of larvae in the last three (B. irene) and two (O. uncatus) larval stadia gave an indication of how recently a larva had moulted. Allocation of larvae to the categories "clean" or "dirty" was not based on quantifiable criteria (Ferreras-Romero \& Corbet, 1999).

To roughly estimate the start of adult emergence of these two species, exuviae were collected biweekly throughout June and July 2013, plus another search in late July 2014 . To estimate the

Table 1. Location and habitat characteristics of the seven sites sampled: ID code, stream name, geographic coordinates, altitude ( $\mathrm{m}$ a.s.I.), type of stream bed (SA - sand; PE - pebble; SR - small rocks; LR - large rocks; BR - bedrock); water speed ( $\mathrm{m} / \mathrm{s}$ ); watercourse width $(\mathrm{m})$; presence (PV) / absence (AV) of riparian vegetation along the banks; and slope (\%o).

\begin{tabular}{ccccccccc}
\hline ID & Stream & Coordinates & Altitude & Bed & Speed & Width & Banks & Slope \\
\hline 1 & Agadón & $40^{\circ} 29^{\prime} 02^{\prime \prime} \mathrm{N}, 06^{\circ} 20^{\prime} 05^{\prime \prime} \mathrm{W}$ & 760 & $\mathrm{SR}+\mathrm{LR}$ & 0.1 & 3.8 & $\mathrm{PV}$ & 12 \\
2 & Frío & $40^{\circ} 19^{\prime} 20^{\prime \prime} \mathrm{N}, 06^{\circ} 38^{\prime} 40^{\prime \prime} \mathrm{W}$ & 830 & $\mathrm{SR}+\mathrm{LR}$ & 0.2 & 16.7 & $\mathrm{PV}$ & 4 \\
3 & Águeda & $40^{\circ} 19^{\prime} 40^{\prime \prime} \mathrm{N}, 06^{\circ} 44^{\prime} 02^{\prime \prime} \mathrm{W}$ & 800 & $\mathrm{PE}+\mathrm{SR}$ & 0.3 & 15.1 & $\mathrm{AV}+\mathrm{PV}$ & 8 \\
4 & Payo & $40^{\circ} 18^{\prime} 03^{\prime \prime} \mathrm{N}, 06^{\circ} 45^{\prime} 34^{\prime \prime} \mathrm{W}$ & 845 & $\mathrm{BR}+\mathrm{PE}$ & 0.2 & 15.1 & $\mathrm{AV}+\mathrm{PV}$ & 40 \\
5 & Perosín & $40^{\circ} 18^{\prime} 57^{\prime \prime} \mathrm{N}, 06^{\circ} 40^{\prime} 03^{\prime \prime} \mathrm{W}$ & 828 & $\mathrm{SA}+\mathrm{SR}$ & 0 & 14.8 & $\mathrm{AV}+\mathrm{PV}$ & 4 \\
6 & Rubioso & $40^{\circ} 16^{\prime} 25^{\prime \prime} \mathrm{N}, 06^{\circ} 47^{\prime} 03^{\prime \prime} \mathrm{W}$ & 900 & $\mathrm{SR}+\mathrm{LR}+\mathrm{BR}$ & 0.1 & 5 & $\mathrm{AV}+\mathrm{PV}$ & 56 \\
7 & Vegas & $40^{\circ} 27^{\prime} 03^{\prime \prime} \mathrm{N}, 06^{\circ} 24^{\prime} 35^{\prime \prime} \mathrm{W}$ & 745 & $\mathrm{PE}+\mathrm{BR}$ & 0.2 & 3.2 & $\mathrm{PV}$ & 20 \\
\hline
\end{tabular}


end of emergence, three additional samples of F-0 exuviae were collected in August and September 2017.

\section{RESULTS}

\section{Boyeria irene}

\section{Determination of larval stadia}

From March 2012 to February 2014, 143 larvae were collected and analysed. Criteria of assignment were head width (HW), length of the metathoracic (hind) wing sheaths (WSL), if present, and the ratio WSL/HW (Tennessen, 2017). F-0 larvae could always be recognized unequivocally because they have the following features: HW range $7.6-8.3 \mathrm{~mm}$, and WSL $8.6-9.3 \mathrm{~mm}$ and reaching the fourth abdominal segment (Fig. 3, Table 2); the ratio WSL/ HW was 1.07-1.13 (mean 1.11). Head width and wingsheath length of F-1 were discrete, WSL range 4.1-5.0 $\mathrm{mm}$, and WSL/HW 0.64-0.71 (mean 0.68). Head width of F-2 and F-3 larvae overlapped (4.9 mm), but WSL was discrete, being $2.1-2.7$ in F-2 and 1.5-1.9 in F-3; the ratio WSL/HW F-2, 0.42-0.49 (mean 0.45), and F-3, 0.33-0.40 (mean 0.36). Apparently, because of the low number of larvae studied, HW and WSL ranges of F-4 are discrete, WSL 1.0-1.4 mm and WSL/HW 0.26-0.33 (mean 0.29). Larvae with a $\mathrm{HW}<3.5 \mathrm{~mm}$ and WSL $<0.9 \mathrm{~mm}$ were assigned to "smaller".

\section{Emergence dates}

From early June 2013 to late July 2014, 141 F-0 exuviae ( 77 females) were collected. Both in Agadón and Frío streams, the earliest exuviae were collected on 4 June 2013 ( $1+$ and $3 \hat{\gamma}$, respectively). During this period, the last exuviae were collected on 24 July 2014 (17ð̄, 20ㅇ) in Agadón

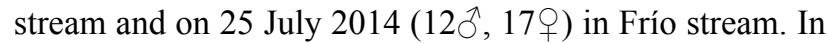
the additional samples collected in August and September 2017, 19 and 29 exuviae belonging to F-0 larvae of $B$. irene were collected, in the Agadón and Frío streams, respectively. The last exuviae were collected on 20 September (1ठ, 2 q) from the Frío stream. Emergence is shown graphically in the upper part of Fig. 4.

\section{Larval development}

Most of the relevant data are summarized in Table 2 and Fig. 4. Due to the low number of larvae collected, the size distributions are fragmentary, and data from all sites and years are evaluated together. Hatching took place in late spring and early summer. During the rest of the season these larvae clearly increased in size to a range in $\mathrm{HW}$ of 2.6 to $4.2 \mathrm{~mm}$, probably F-6 to F-4, in which they spent all winter (their first as larvae) into spring. During the following summer, their second in the larval stage, these larvae grew slowly and many reached F-1, a few F-0, during autumn, overwintered and emerged during the next summer, thus completing their development in three years (partivoltinism). The relatively numerous overwintering F-2 larvae must also have emerged the following summer, but their origin and age may be complex.

From Table 2, it appears that the overwintering F-2 larvae belonged to the cohort of older larvae, with a three year development. This is reinforced by the absence of larvae clas-

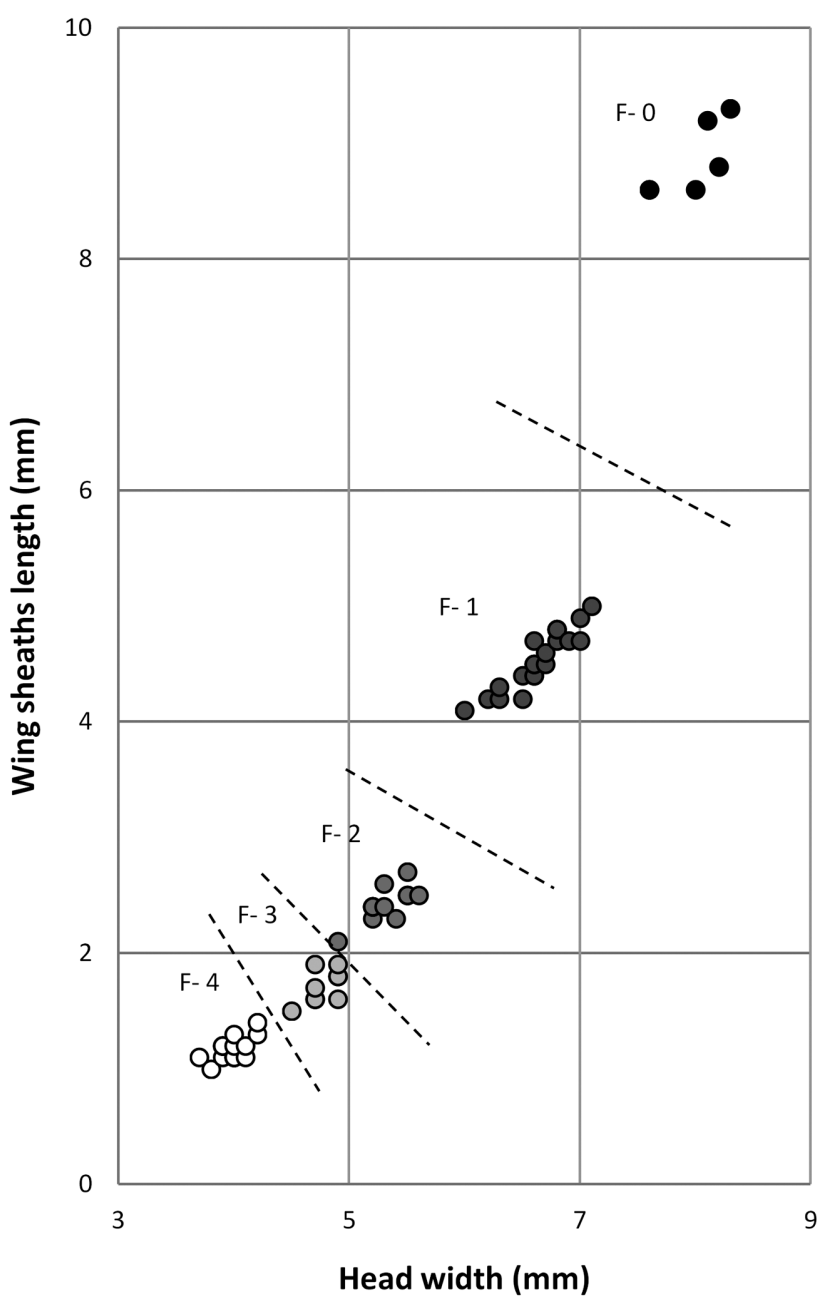

Fig. 3. Boyeria irene. Relationship between head width and wingsheath length of larvae collected at all localities. Broken lines separate the last five stadia assigned to F-0 to F-4, the data for which are presented as roundels in different shades of colour from black to white.

sified as F-3 from August to March, and this gap separates the F-2 larvae from the cohort of smaller larvae. However, the actual sizes of the larvae, also shown in Fig. 4, indicate that the relatively big F-4 (based on their HW and WSL) in September-October may have functioned as F-3, which gave rise to the small overwintering F-2 (Table 2). This was also supported by the sample collected from Agadón stream in 2011, but not included in this study, which included four big F-4 larvae (HW range 4.0-4.4 mm, WSL/ HW ratios $0.30-0.32$ ) already on 11 September. During the following spring and summer the small F-2 produced small F-1 (April and May) and F-0 (June), which then emerged. They were semivoltine and contributed to the later part of that years emergence. Maybe overwintering F-3 and some large "F-4" that were not collected may have also emerged during the following season, adding still later emergences (September). Finds of exuviae support this scenario: one F-4 in late September and one F-3 in early April.

The smaller F-4 larvae during winter and spring clearly moulted into big F-3 from April to July and overlapped in size with overwintering F-2 (Fig. 4). The latter had a WSL/ $\mathrm{HW}$ ratio of 0.43 , compared to $0.37-0.39$ in the similarly 
Table 2. Boyeria irene. Monthly range and mean of larval head widths $(\mathrm{mm})$ of the last five stadia, and collectively of the smaller larvae, from March 2012 to February 2014, all sites combined. In the heading, the numbers of larvae from Agadón and Frío are shown in parentheses. For each stadium, the total number of larvae measured each month are shown in square brackets. The monthly percentages for each stadium for larvae only collected from Agadón and Frío are shown in parentheses. Evidence of recruitment is shown in bold and italics. The likely moulting of the younger cohort into F-2 in the first year is indicated by arrows.

\begin{tabular}{|c|c|c|c|c|c|c|}
\hline $\begin{array}{l}\text { Months in } 2012-2014 \\
\quad \mathrm{~N}=143(105)\end{array}$ & $\begin{array}{c}\mathrm{F}-0 \\
\mathrm{~N}=6(4)\end{array}$ & $\begin{array}{c}\mathrm{F}-1 \\
\mathrm{~N}=20(17)\end{array}$ & $\begin{array}{c}\mathrm{F}-2 \\
\mathrm{~N}=13(9)\end{array}$ & $\begin{array}{c}F-3 \\
N=9(9)\end{array}$ & $\begin{array}{c}\mathrm{F}-4 \\
\mathrm{~N}=15(12)\end{array}$ & $\begin{array}{l}\text { Smaller larvae } \\
\quad N=80(54)\end{array}$ \\
\hline $\begin{array}{c}\text { March } \\
\text { (2012 \& 2013) }\end{array}$ & - & - & - & - & $\begin{array}{c}4.0[1] \\
(8 \%)\end{array}$ & $\begin{array}{c}2.6-3.4[3] \\
x=3.03 \\
(6 \%)\end{array}$ \\
\hline April & - & $\begin{array}{c}6.2-6.5[4] \\
x=6.33 \\
(12 \%)\end{array}$ & - & $\begin{array}{l}4.7[1] \\
(11 \%)\end{array}$ & $\begin{array}{c}4.0[1] \\
(-\%)\end{array}$ & $\begin{array}{c}3.1-3.4[2] \\
x=3.25 \\
(-\%)\end{array}$ \\
\hline May & $\begin{array}{l}8.0[1] \\
(25 \%)\end{array}$ & $\begin{array}{c}6.0[1] \\
(6 \%)\end{array}$ & - & $\begin{array}{c}4.5-4.9[2] \\
x=4.70 \\
(22 \%)\end{array}$ & $\begin{array}{c}3.8-4.0[3] \\
x=3.93 \\
(25 \%)\end{array}$ & $\begin{array}{c}0.9-3.1[2] \\
x=(\text { different cohort }) \\
(4 \%)\end{array}$ \\
\hline June & $\begin{array}{c}7.6[2] \\
x=7.60 \\
(25 \%)\end{array}$ & - & - & $\begin{array}{c}4.7-4.9[5] \\
x=4.78 \\
(56 \%)\end{array}$ & - & $\begin{array}{c}0.7-1.3[29] \\
x=0.96 \\
(17 \%)\end{array}$ \\
\hline July & - & - & $\begin{array}{c}5.5-5.6[2] \\
x=5.55 \\
(22 \%)\end{array}$ & $\begin{array}{l}4.9[1] \\
(11 \%)\end{array}$ & - & $\begin{array}{c}1.1-2.4[10] \\
x=1.72 \\
(19 \%)\end{array}$ \\
\hline August & - & $\begin{array}{c}6.5-6.9[3] \\
x=6.73 \\
(18 \%)\end{array}$ & $\begin{array}{l}5.5[1] \\
(11 \%)\end{array}$ & - & - & $\begin{array}{c}1.8-3.4[16] \\
x=2.26 \\
(30 \%)\end{array}$ \\
\hline September & - & $\begin{array}{c}6.6-7.0[2] \\
x=6.80 \\
(12 \%)\end{array}$ & $\begin{array}{c}5.2[1] \\
(-\%)\end{array}$ & - & $\begin{array}{c}4.2[1] \\
(-\%)\end{array}$ & $\begin{array}{c}2.4-3.4[8] \\
x=2.90 \\
(11 \%)\end{array}$ \\
\hline October & - & $\begin{array}{c}6.8-7.1[2] \\
x=6.95 \\
(12 \%)\end{array}$ & $\begin{array}{c}5.2[1] \\
x=5.20 \\
(11 \%)\end{array}$ & - & $\begin{array}{c}3.9-4.2[4] \\
x=4.03 \\
(33 \%)\end{array}$ & $\begin{array}{c}2.6-3.2[6] \\
x=3.00 \\
(11 \%)\end{array}$ \\
\hline November & $\begin{array}{l}8.1[1] \\
(25 \%)\end{array}$ & $\begin{array}{c}6.6[1] \\
(6 \%)\end{array}$ & $\begin{array}{l}5.3[1] \\
(11 \%)\end{array}$ & - & $\begin{array}{c}3.7[1] \\
(8 \%)\end{array}$ & $\begin{array}{c}2.7[1] \\
(2 \%)\end{array}$ \\
\hline December & - & $\begin{array}{c}6.6[2] \\
x=6.60 \\
(6 \%)\end{array}$ & $\begin{array}{c}5.4-5.5[2] \\
x=5.45 \\
(22 \%)\end{array}$ & - & - & - \\
\hline $\begin{array}{c}\text { January } \\
\text { (2013 \& 2014) }\end{array}$ & $\begin{array}{c}8.2-8.3[2] \\
x=8.25 \\
(25 \%)\end{array}$ & $\begin{array}{c}6.6-6.8[4] \\
x=6.70 \\
(24 \%)\end{array}$ & $\begin{array}{c}4.9-5.3[5] \\
x=5.16 \\
(22 \%)\end{array}$ & - & $\begin{array}{c}4.1[1] \\
(-\%)\end{array}$ & $\begin{array}{c}2.9-3.2[3] \\
x=3.10 \\
(2 \%)\end{array}$ \\
\hline February & - & $\begin{array}{c}7.0[1] \\
(6 \%)\end{array}$ & - & - & $\begin{array}{c}3.9-4.0[3] \\
x=3.93 \\
(25 \%)\end{array}$ & - \\
\hline
\end{tabular}

sized F-3. Later in summer, these F-3 gave rise to big F-2, and these to the big overwintering F-1 and F-0. Some F-2 with this background may also have overwintered (HW: $5.4-5.5 \mathrm{~mm}$ ). An exuvia assigned to F-4 found in late July indicates that relatively small larvae were still around at that time. So, the F-2 stadium in autumn could indicate the start point of "cohort-merging" (Fig. 4).

During late autumn through winter (November-January) and in July, some F-2 larvae had a thick coating of particles on the body surface, "dirty" larvae (Table 3), indicating they had spent a long time in that stadium; so, there was a slowing down of the growth of F-2 larvae during that period. The occurrence of "clean", recently moulted F-2 larvae from August to October indicate passage to the F-2 stadium during this period (autumnal growth, F-3 $\rightarrow \mathrm{F}-2$ ). Some may belong to the partivoltine component, but the small F-2 larvae in September-October are quite likely to be semivoltine. During April and May, overwintering F-2 larvae moulted to small, "clean" F-1 (probably the semivoltine component). Also in December a relatively big, "clean" F-1 larva, which had recently moulted from the F-2 stadium (partivoltine component), was collected. "Clean" F-0 larvae were found during spring and early summer, indicating growth from F-1 to emergence. "Dirty" F-0 and F-1 larvae found in autumn and winter were obviously overwintering.

In the late autumn and winter samples (NovemberMarch) the numbers of larvae in both F-1 and F-2 were nearly three times greater than in F-0 (Table 2). Since only a few larvae seemed to spend their last winter as $\mathrm{F}-0, B$. irene is a typical "summer species" sensu Corbet (1964).

\section{Onychogomphus uncatus}

\section{Determination of larval stadia}

From March 2012 to February 2014, 1726 larvae were collected and analysed. Criteria of assignment were the same as for $B$. irene. F-0 larvae could always be recognized unequivocally as they have the following features: HW 5.1-5.9 mm, and WSL 6.1-7.2 $\mathrm{mm}$, which reach the fourth abdominal segment; the ratio WSL/HW is $1.11-1.28$ 


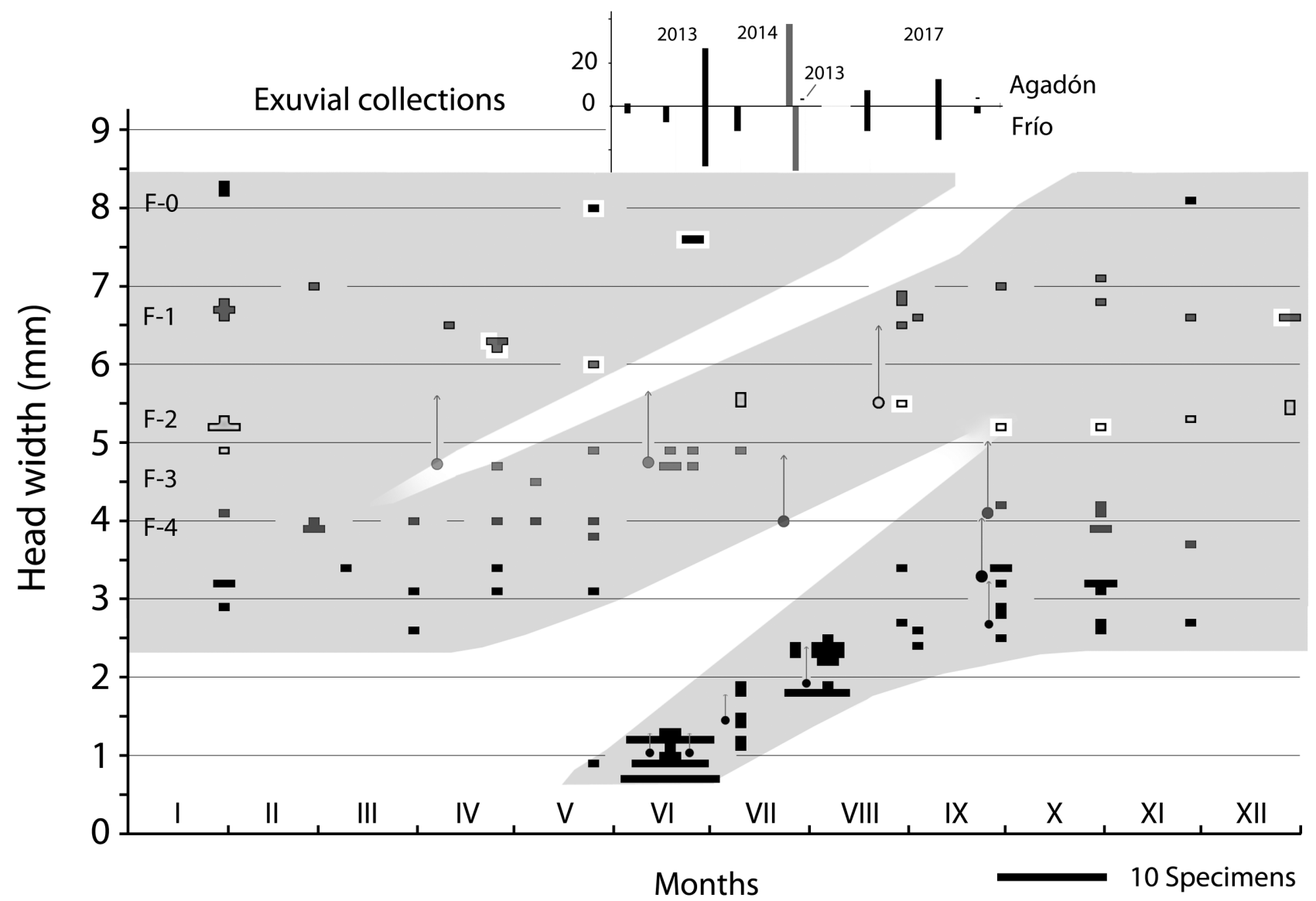

Fig. 4. Kite diagram summarizing the larval development data of Boyeria irene, collected at all sites, from March 2012 to February 2014. Likely development paths are shown shaded. Samples collected on similar dates are merged for practical reasons. "Clean" (newly moulted) larvae were recorded for F-0 to F-2, and are indicated by being surrounded by white areas. The last five stadia, which were assigned biometrically, are coded by different shadings. Round symbols, with stadium coding, are for exuviae collected in the water and assigned to stadium categories (F-5 to F-1, and smaller), and roughly placed left of the sampling date and at an approximate head width, arrows indicate the likely size increase at the moult. Each symbol for small larvae (pre-F-5) is sometimes based on many exuviae. Numbers of F-0 exuviae collected are shown as histograms for the inspection dates (width of columns 2 days). Inspections when no exuviae were found are indicated by "-". The single samples from 2014 are in grey.

(mean 1.22) (Table 4). There is almost a consistent overlap from F-1 to F-4 in all criteria, which indicate some uncertainty in the assignment, in particular in the lower range. Larvae with head widths less than $2.4 \mathrm{~mm}$ and wing-sheath length less than $0.5 \mathrm{~mm}$ were assigned to "smaller". F-3 and F-4 did in fact form a fused, relatively wide peak in both head width and wing pad length, which is separated from the peaks of both smaller larvae, and in particular from F-2 (Fig. 5).

\section{Emergence dates}

In late June and early and late July 2013, 47 F-0 exuviae (21 females) were collected. Both from Agadón and Frío streams, the earliest and most numerous exuviae were

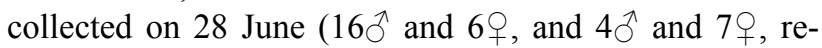
spectively). During this period, the last exuviae were collected on 28 July ( $4 \curvearrowright$ and 19 ) from Agadón stream. In the additional samples carried out in August and September 2017, six F-0 exuviae (three females) were found, all in Frío stream; the last on 8 September ( $2 \widehat{\bigcirc}$ and 1 우).

Table 3. Boyeria irene. Monthly records of "clean" (recently moulted) and "dirty" late stadium larvae, showing temporal patterns of moulting into the three last stadia. Head widths $(\mathrm{mm})$ of specimens are shown in parentheses.

\begin{tabular}{|c|c|c|c|c|c|c|c|c|c|}
\hline Stadium & & $=-2$ & & & $\mathrm{~F}-1$ & & & $\mathrm{~F}-0$ & \\
\hline Stream & Agadón & Frío & $\begin{array}{c}\text { Other } \\
\text { streams }\end{array}$ & Agadón & Frío & $\begin{array}{c}\text { Other } \\
\text { streams }\end{array}$ & Agadón & Frío & $\begin{array}{c}\text { Other } \\
\text { streams }\end{array}$ \\
\hline Clean & Oct (5.2) & Aug (5.5) & Sep (5.2) & - & Dec (6.6), May (6.0) & Apr $(6.2,6.3)$ & Jun (7.6) & May (8.0) & Jun (7.6) \\
\hline Dirty & $\begin{array}{c}\text { Nov (5.3), Dec (5.4) } \\
\text { Jan }(5.2,5.3) \\
\text { Jul }(5.6)\end{array}$ & $\begin{array}{l}\operatorname{Dec}(5.5) \\
\text { Jul }(5.5)\end{array}$ & $\begin{array}{l}\text { Jan }(4.9 \\
5.2,5.2)\end{array}$ & $\begin{array}{c}\text { Oct (7.1) Nov (6.6) } \\
\text { Dec (6.6) Feb (7.0) } \\
\operatorname{Mar}(6.3,6.5)\end{array}$ & $\begin{array}{c}\text { Sep }(7.0) \\
\text { Jan }(6.6,6.7,6.7,6.8) \\
\text { Aug }(6.5)\end{array}$ & Sep (6.6) & $\begin{array}{l}\text { Nov (8.2) } \\
\operatorname{Jan}(8.1)\end{array}$ & & Jan (8.3) \\
\hline
\end{tabular}




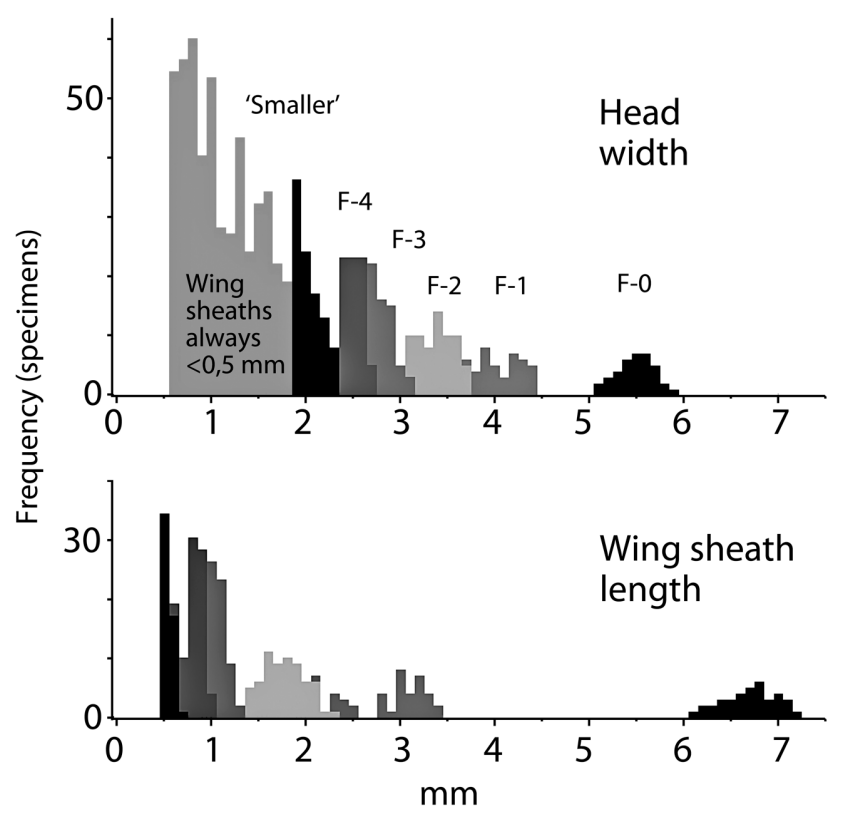

Fig. 5. Onychogomphus uncatus. Head widths ( $>0.5 \mathrm{~mm}$ only) and wing sheath lengths $(>0.4 \mathrm{~mm}$ only) of all samples collected from Agadón and Frío streams. The last five larval stadia are shown as assigned (F-4 to F-0) and some "smaller larvae" are included. Stadium shadings are reminiscent of those in Fig. 6. Larvae with $<1.9$ $\mathrm{mm}$ head width (grey) always have wing sheaths $<0.5 \mathrm{~mm}$, but this also applies to many of the larvae (black) just above this size.
Table 4. Onychogomphus uncatus. Ranges in head widths (HW), wing sheath length (WSL) in $\mathrm{mm}$ and their ratio (HW/WSL) for the different stadium groups (number of larvae in parentheses). For WSL and HW/WSL reduced ranges containing $90 \%$ or more of the specimens are shown for some stadia. For HW/WSL mean values are also given.

\begin{tabular}{lccc}
\hline $\begin{array}{l}\text { Stadium } \\
\text { assignment }\end{array}$ & $\mathrm{HW}$ & $\mathrm{WSL}$ & WSL/HW (mean) \\
\hline $\mathrm{F}-0(\mathrm{~N}=54)$ & $5.1-5.9$ & $6.1-7.2$ & $1.11-1.28(1.22)$ \\
\hline $\mathrm{F}-1(\mathrm{~N}=55)$ & $3.7-4.4$ & $\begin{array}{c}2.1-3.4 \\
(98 \% 2.3-3.4)\end{array}$ & $\begin{array}{c}0.55-0.79(0.72) \\
(91 \% 0.64-0.79)\end{array}$ \\
\hline $\mathrm{F}-2(\mathrm{~N}=83)$ & $3.1-3.7$ & $\begin{array}{c}1.4-2.3 \\
(98 \% 1.4-2.1)\end{array}$ & $\begin{array}{l}0.43-0.67(0.52) \\
(94 \% 0.45-0.60)\end{array}$ \\
\hline $\mathrm{F}-3(\mathrm{~N}=69)$ & $2.7-3.1$ & $1.0-1.3$ & $\begin{array}{l}0.34-0.43(0.38) \\
(94 \% 0.34-0.41)\end{array}$ \\
\hline $\mathrm{F}-4(\mathrm{~N}=88)$ & $2.4-2.7$ & $0.5-1.0$ & $\begin{array}{l}0.21-0.40(0.33) \\
(90 \% 0.25-0.36)\end{array}$ \\
\hline "smaller" & $<2.4$ & $<0.5$ & \\
\hline
\end{tabular}

\section{Larval development}

Most of the relevant data are summarized in Table 5 and Fig. 6. Also in this species the number of larvae sampled varied greatly and was low for the last five stadia. A preliminary analysis, with the data for streams and years separated, indicated that the differences between the years studied and the two continuously sampled streams, Frío

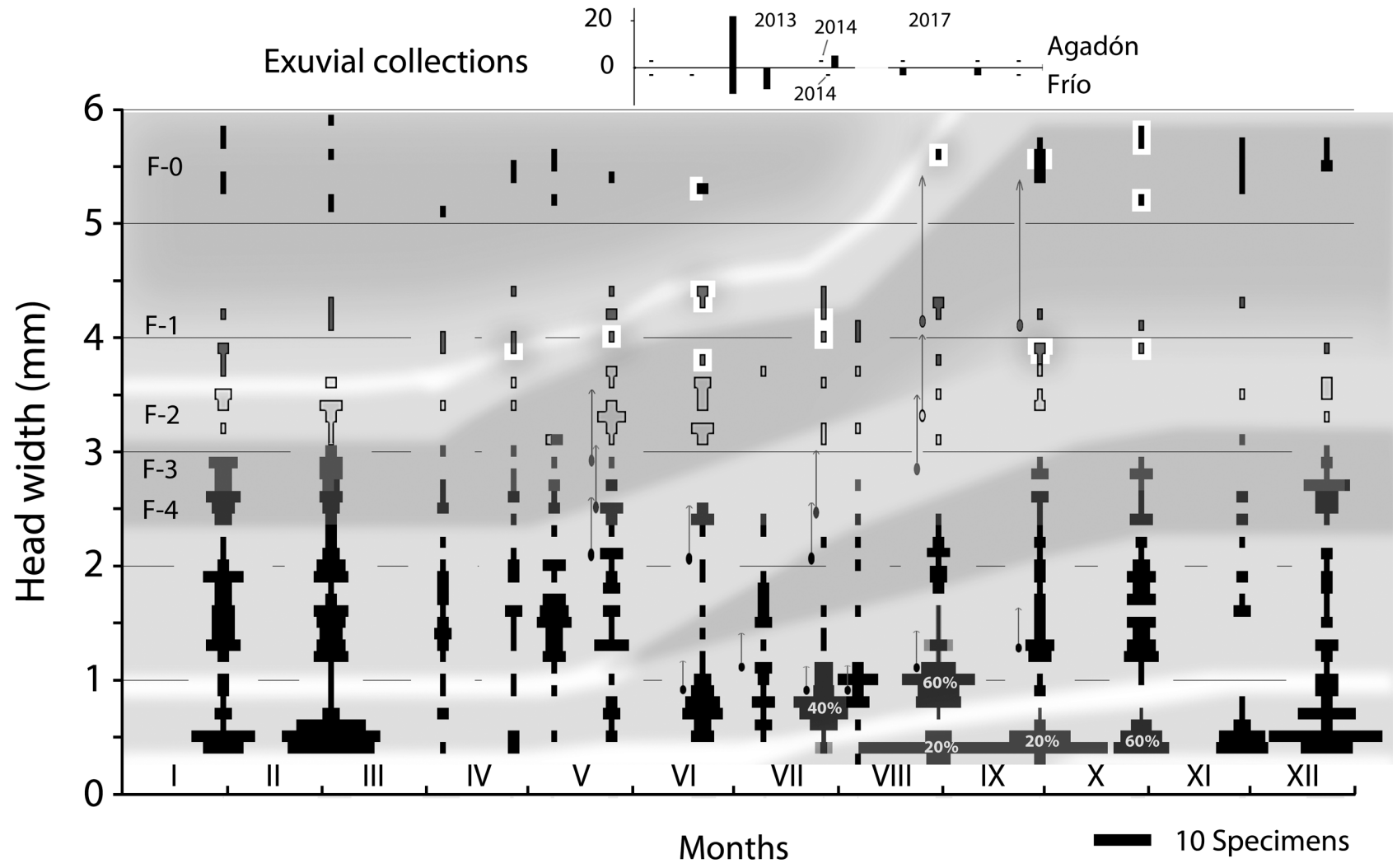

Fig. 6. Kite diagram summarizing larval development of Onychogomphus uncatus from March 2012 to February 2014, based only on the collections from Frío and Agadón streams. The graph is essentially similar to Fig. 4, but exuviae collected in the water are here shown as ovals. Darker shading indicate possible cohort overlaps. Many samples collected on similar dates (span at most 11 days) are merged, even across months, and assigned a weighted average date. To make it easier to read, parts of some large samples are reduced in scale to the percentage indicated. "Clean" (newly moulted) larvae were recorded for F-0 and F-1 only. 


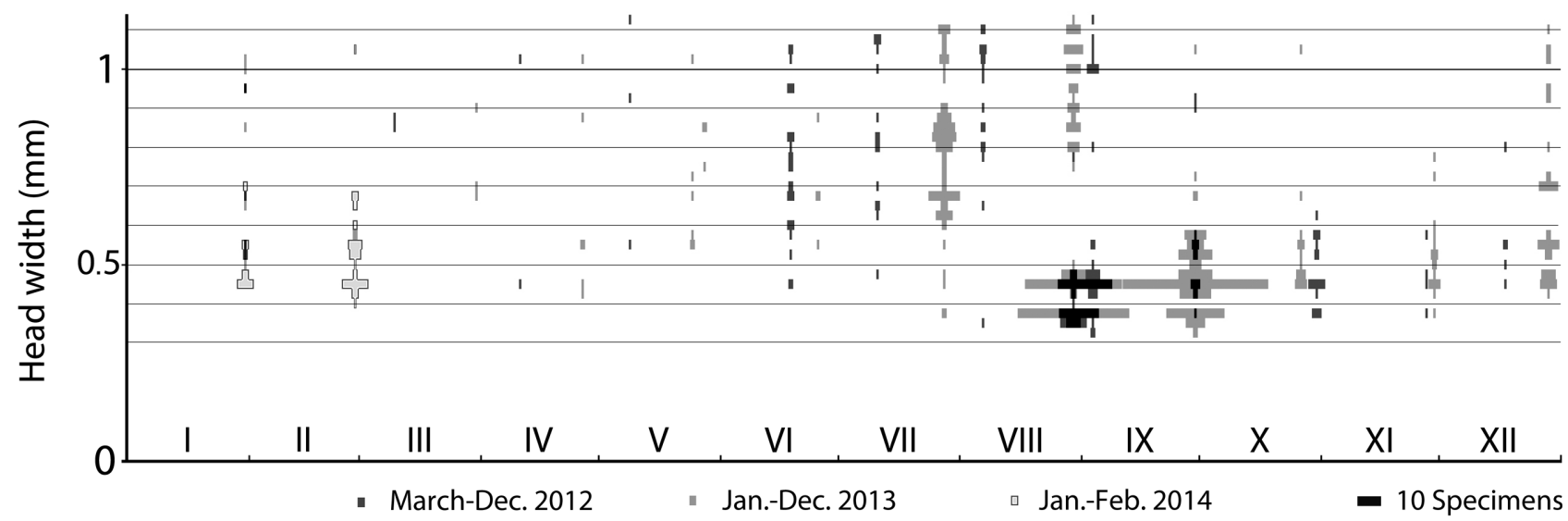

Fig. 7. Onychogomphus uncatus. High-resolution graph of the head widths of small larvae $(\mathrm{HW}<1.2 \mathrm{~mm})$. Hatchling larvae $(\mathrm{HW}<0.4 \mathrm{~mm})$ were collected from late July to late November. There were also single larvae around HW 0.5 and $0.6 \mathrm{~mm}$ recorded in late July, and ca. 0.5 $\mathrm{mm}$ in June and early July, certainly from an older cohort. The smallest of these overwintering larvae formed a peak at HW $0.45-0.55 \mathrm{~mm}$.

and Agadón, were minor or non-existent. Therefore, the data from Frío and Agadón, and the different years, were pooled. The more scattered data from the supplementary sampling sites in other streams (Table 1) were not included in Fig. 6.

The smallest larvae (HW around $0.35 \mathrm{~mm}$ ) were collected in late August and September, but slightly bigger larvae

Table 5. Onychogomphus uncatus. Monthly range and mean of larval head widths (mm) of the last five stadia, and collectively for the smaller larvae, from March 2012 to February 2014, all sites combined. The table is arranged in the same way as Table 2.

\begin{tabular}{|c|c|c|c|c|c|c|}
\hline $\begin{array}{l}\text { Months in } 2012-2014 \\
\quad \mathrm{~N}=1726(1368)\end{array}$ & $\begin{aligned} & F-0 \\
N= & 54(37)\end{aligned}$ & $\begin{aligned} & F-1 \\
N= & 55(39)\end{aligned}$ & $\begin{array}{c}\mathrm{F}-2 \\
\mathrm{~N}=83(64)\end{array}$ & $\begin{array}{c}\mathrm{F}-3 \\
\mathrm{~N}=69(56)\end{array}$ & $\begin{array}{c}\mathrm{F}-4 \\
\mathrm{~N}=88(74)\end{array}$ & $\begin{array}{c}\text { Smaller } \\
\mathrm{N}=1377(1098)\end{array}$ \\
\hline $\begin{array}{c}\text { March } \\
(2012 \& 2013)\end{array}$ & $\begin{array}{c}5.2-5.9[2] \\
x=5.55 \\
(5.40 \%)\end{array}$ & - & $\begin{array}{c}3.1-3.6[5] \\
x=3.34 \\
(7.81 \%)\end{array}$ & $\begin{array}{c}2.8-3.0[3] \\
x=2.93 \\
(5.36 \%)\end{array}$ & $\begin{array}{c}2.5[2] \\
x=2.50 \\
(2.70 \%)\end{array}$ & $\begin{array}{c}0.7-2.2[28] \\
x=1.45 \\
(2.55 \%)\end{array}$ \\
\hline April & $\begin{array}{c}5.1-5.7[11] \\
x=5.42 \\
(8.11 \%)\end{array}$ & $\begin{array}{c}3.7-4.4[9] \\
x=3.97 \\
(12.82 \%)\end{array}$ & $\begin{array}{c}3.1-3.6[9] \\
x=3.37 \\
(4.69 \%)\end{array}$ & $\begin{array}{c}2.7-3.0[8] \\
x=2.79 \\
(5.36 \%)\end{array}$ & $\begin{array}{c}2.4-2.7[7] \\
x=2.54 \\
(8.11 \%)\end{array}$ & $\begin{array}{c}0.4-2.2[54] \\
x=1.51 \\
(3.01 \%)\end{array}$ \\
\hline May & $\begin{array}{c}5.2-5.6[4] \\
x=5.42 \\
(10.81 \%)\end{array}$ & $\begin{array}{c}4.0-4.4[4] \\
x=4.20 \\
(10.26 \%)\end{array}$ & $\begin{array}{c}3.1-3.7[14] \\
x=3.35 \\
(21.87 \%)\end{array}$ & $\begin{array}{c}2.7-3.1[6] \\
x=2.90 \\
(10.71 \%)\end{array}$ & $\begin{array}{c}2.4-2.7[11] \\
x=2.53 \\
(14.86 \%)\end{array}$ & $\begin{array}{c}0.5-2.3[65] \\
x=1.46 \\
(5.92 \%)\end{array}$ \\
\hline June & $\begin{array}{c}5.3-5.4[4] \\
x=5.35 \\
(5.40 \%)\end{array}$ & $\begin{array}{c}3.8-4.4[7] \\
x=4.20 \\
(10.26 \%)\end{array}$ & $\begin{array}{c}3.1-3.6[22] \\
x=3.35 \\
(20.31 \%)\end{array}$ & $\begin{array}{c}2.7[1] \\
(-\%)\end{array}$ & $\begin{array}{c}2.4-2.6[12] \\
x=2.47 \\
(8.11 \%)\end{array}$ & $\begin{array}{c}0.5-2.3[151] \\
x=1.05 \\
(3.10 \%)\end{array}$ \\
\hline July & - & $\begin{array}{c}4.0-4.4[4] \\
x=4.22 \\
(10.26 \%)\end{array}$ & $\begin{array}{c}3.1-3.7[4] \\
x=3.40 \\
(6.25 \%)\end{array}$ & - & $\begin{array}{c}2.4[1] \\
(1.35 \%)\end{array}$ & $\begin{array}{c}0.4-2.3[120] \\
x=0.91 \\
(10.93 \%) \\
\end{array}$ \\
\hline August & $\begin{array}{l}5.60[1] \\
(2.70 \%)\end{array}$ & $\begin{array}{c}3.8-4.3[6] \\
x=4,12 \\
(15.38 \%)\end{array}$ & $\begin{array}{c}3.1-3.7[4] \\
x=3.37 \\
(6.25 \%)\end{array}$ & $\begin{array}{c}2.7[1] \\
(1.79 \%)\end{array}$ & $\begin{array}{c}2.4[1] \\
(1.35 \%)\end{array}$ & $\begin{array}{c}\text { ca. } 0.3-2.2[231] \\
x=0.60 \\
(21.04 \%)\end{array}$ \\
\hline September & $\begin{array}{c}5.4-5.7[14] \\
x=5.52 \\
(18.92 \%) \\
\end{array}$ & $\begin{array}{c}3.8-4.2[10] \\
x=4.04 \\
(10.26 \%)\end{array}$ & $\begin{array}{c}3.3-3.7[5] \\
x=3.46 \\
(6.25 \%)\end{array}$ & $\begin{array}{c}2.7-3.0[7] \\
x=2.84 \\
(7.14 \%)\end{array}$ & $\begin{array}{c}2.4-2.7[8] \\
x=2.52 \\
(8.11 \%)\end{array}$ & $\begin{array}{c}\text { ca. } 0.3-2.3[408] \\
x=0.67 \\
(25.05 \%)\end{array}$ \\
\hline October & $\begin{array}{c}5.2-5.8[3] \\
x=5.57 \\
(8.11 \%)\end{array}$ & $\begin{array}{c}3.9-4.1[2] \\
x=4.00 \\
(5.13 \%)\end{array}$ & - & $\begin{array}{c}2.7-2.9[6] \\
x=2.80 \\
(10.71 \%)\end{array}$ & $\begin{array}{c}2.40-2.60[6] \\
x=2.45 \\
(8.11 \%)\end{array}$ & $\begin{array}{c}0.4-2.2[75] \\
x=1.07 \\
(6.83 \%)\end{array}$ \\
\hline November & $\begin{array}{c}5.3-5.7[5] \\
x=5.50 \\
(13.51 \%)\end{array}$ & $\begin{array}{c}4.3[1] \\
(2.56 \%)\end{array}$ & $\begin{array}{c}3.5[1] \\
(1.56 \%)\end{array}$ & $\begin{array}{c}3.1[1] \\
(1.79 \%)\end{array}$ & $\begin{array}{c}2.4-2.6[4] \\
x=2.50 \\
(5.41 \%)\end{array}$ & $\begin{array}{c}0.4-2.2[29] \\
x=0.81 \\
(2.64 \%)\end{array}$ \\
\hline December & $\begin{array}{c}5.5-5.7[4] \\
x=5.57 \\
(10.81 \%)\end{array}$ & $\begin{array}{l}3.9[1] \\
(2.56 \%)\end{array}$ & $\begin{array}{c}3.3-3.6[5] \\
x=3.50 \\
(7.81 \%)\end{array}$ & $\begin{array}{c}2.7-3.0[11] \\
x=2.77 \\
(19.64 \%)\end{array}$ & $\begin{array}{c}2.4-2.7[10] \\
x=2.55 \\
(13.51 \%)\end{array}$ & $\begin{array}{c}0.4-2.1[69] \\
x=0.86 \\
(6.28 \%)\end{array}$ \\
\hline $\begin{array}{c}\text { January } \\
\text { (2013 \& 2014) }\end{array}$ & $\begin{array}{c}5.30-5.80[4] \\
x=5.55 \\
(10.81 \%) \\
\end{array}$ & $\begin{array}{c}3.7-4.2[8] \\
x=3.91 \\
(12.82 \%)\end{array}$ & $\begin{array}{c}3.1-3.5[9] \\
x=3.32 \\
(9.37 \%)\end{array}$ & $\begin{array}{c}2.7-2.9[15] \\
x=2.80 \\
(19.64 \%)\end{array}$ & $\begin{array}{c}2.4-2.6[17] \\
x=2.51 \\
(16.22 \%)\end{array}$ & $\begin{array}{c}0.4-2.3[71] \\
x=1.19 \\
(5.74 \%)\end{array}$ \\
\hline February & $\begin{array}{c}5.1-5.6[2] \\
x=5.35 \\
(5.40 \%)\end{array}$ & $\begin{array}{c}4.1-4.3[3] \\
x=4.20 \\
(7.69 \%)\end{array}$ & $\begin{array}{c}3.3-3.6[5] \\
x=3.40 \\
(7.81 \%)\end{array}$ & $\begin{array}{c}2.7-3.0[10] \\
x=2.84 \\
(17.86 \%)\end{array}$ & $\begin{array}{c}2.4-2.7[9] \\
x=2.54 \\
(12.16 \%)\end{array}$ & $\begin{array}{c}0.4-2.3[76] \\
x=0.96 \\
(6.92 \%)\end{array}$ \\
\hline
\end{tabular}


Table 6. Onychogomphus uncatus. Monthly records of "clean" (recently moulted) and "dirty" late stadium larvae, showing temporal patterns in moulting into the two last stadia. Head widths $(\mathrm{mm})$ of specimens are shown in parentheses.

\begin{tabular}{|c|c|c|c|c|c|c|}
\hline Stadium & & $\mathrm{F}-1$ & & & $\mathrm{~F}-0$ & \\
\hline Stream & Agadón & Frío & Other streams & Agadón & Frío & Other streams \\
\hline Clean & $\begin{array}{c}\text { May }(4.0) \\
\text { Jun }(4.3,4.4,4.4) \\
\text { Jul }(4.2) \\
\text { Sep }(3.8,3.9) \\
\text { Oct }(3.9) \\
\end{array}$ & $\begin{array}{l}\text { Apr (3.9) } \\
\text { Jun (3.8) } \\
\text { Jul (4.0) } \\
\text { Sep (3.9) }\end{array}$ & $\begin{array}{c}\text { Apr }(3.9,4.0) \\
\text { Sep }(4.0,4.1) \\
\text { Sep }(3.9) \\
\text { Jun }(4.4)\end{array}$ & $\begin{array}{c}\text { Jun }(5.3) \\
\text { Sep }(5.6) \\
\text { Oct }(5.2,5.7,5.8)\end{array}$ & $\begin{array}{c}\text { Aug }(5.6) \\
\text { Sep }(5.5,5.5,5.6)\end{array}$ & $\begin{array}{c}\text { Sep }(5.4,5.5,5.5,5.6,5.6) \\
\text { Jun }(5.4,5.4) \\
\text { Apr }(5.5) \\
\operatorname{Sep}(5.6)\end{array}$ \\
\hline Dirty & $\begin{array}{c}\text { Jan }(3.9) \\
\text { Feb }(4.2,4.3) \\
\text { Apr }(4.4) \\
\text { May (4.4) } \\
\text { Jul }(4.4) \\
\text { Aug (4.1) }\end{array}$ & $\begin{array}{c}\text { Jan }(3.7,3.8,3.9,4.2 \\
\text { Feb }(4.1) \\
\text { Apr }(3.9,4.0,4.0) \\
\text { May }(4.2,4.2) \\
\text { Jul }(4.3) \\
\text { Aug }(3.8,4.2,4.3) \\
\text { Sep (4.2), Oct }(4.1) \\
\text { Nov (4.3), Dec (3.9) }\end{array}$ & $\begin{array}{c}\text { Jan }(3.9,4.0) \\
\text { Jun }(3.9) \\
\text { Apr }(3.9) \\
\text { Sep }(4.2) \\
\text { Sep }(4.2) \\
\text { Jan }(3.9) \\
\text { Apr }(3.7) \\
\text { Sept }(4.2)\end{array}$ & $\begin{array}{c}\operatorname{Jan}(5.4) \\
\text { Feb }(5.1,5.6) \\
\operatorname{Mar}(5.2,5.9) \\
\operatorname{Apr}(5.1,5.5) \\
\text { May }(5.2,5.4,5.5,5.6) \\
\operatorname{Jun}(5.3) \\
\text { Nov }(5.3,5.4,5.5,5.6,5.7) \\
\operatorname{Dec}(5.5,5.6,5.7)\end{array}$ & $\begin{array}{c}\operatorname{Jan}(5.3,5.7,5.8) \\
\text { Apr }(5.4) \\
\text { Sep }(5.4,5.4,5.7) \\
\text { Dec }(5.5) \\
\end{array}$ & $\begin{array}{c}\text { Apr }(5.5,5.7) \\
\operatorname{Apr}(5.4,5.5) \\
\operatorname{Sep}(5.4) \\
\operatorname{Apr}(5.3,5.3,5.4)\end{array}$ \\
\hline
\end{tabular}

(HW just below $0.4 \mathrm{~mm}$ ) were found in late July to late November. The latter formed the sharp peaks recorded in August-September (Fig. 7), the time when the smallest larvae are also present. A re-examination of the samples indicated that all these larvae were hatchlings, and that the smallest head widths were often the consequence of preserving still soft and fresh specimens. There were also single larvae around HW 0.45 and $0.55 \mathrm{~mm}$ in late July, and 0.45 to $0.48 \mathrm{~mm}$ in June and early July (Fig. 7), almost certainly belonging to an older cohort.

In the following we consider the first season (or summer) in their development to be the one when hatching took place, before the first winter. During the first autumn these larvae slowly grew to a size with a head width of less than $1 \mathrm{~mm}$, in which they spent their first winter, some evidently having only moulted once (Fig. 7).

After the first winter as larvae, during the second summer, most of the larvae grew slowly and during their second winter had a HW between ca. 1.2-2.2 $\mathrm{mm}$. This growth rate correlated well with their slow growth in the first autumn. Simultaneously, some fast-growing larvae might have had a HW of up to $3 \mathrm{~mm}$ by achieving a very high growth rate during their second summer-autumn (Fig. 6 , darker shading); but the samples were often small and irregular, and the cohorts now confluent. The biggest of the latter larvae were classified as F-3 (Table 5).

After their second winter, interpretation of growth becomes increasingly uncertain because of overlap between cohorts. Of those overwintering with head widths of 1.2 to $2.2 \mathrm{~mm}$, at least the smaller spent their third winter in the F-3/F-4 stadium peak, which possibly overlapped that of a younger cohort (Fig. 6, darker shading). This slow path of development was similar to that recorded for most larvae in the previous seasons (two youngest cohorts). Simultaneously, some larvae in this cohort probably reached F-2, or even F-1 in their third winter, and consequently some specimens completed their development in three years.

Those spending their third winter in F-3/F-4 stadia, at least started to enter F-2 in May (exuvial finds, cf. Fig. 6). From June onwards there was an indication of a cohort split, in which many of the bigger larvae (F-2), probably coming from the F-3/F-4 peak, reached F-0 by the follow- ing winter (the fourth), and so developed in four years. There were virtually no F-3 from June to August, but samples were very small and did not clearly corroborate the split. If any larvae spent their second winter in F-3/F-4, then these could have developed in three years.

From late October to early April (cf. Fig. 6), which is probably the winter period, at least for big larvae, there were 21 F-0 and 14 F-1. Overwintering F-0 larvae started to emerge in the latter part of June, and considering that they may continue to emerge into August and even September, at least the overwintering F-1 should have emerged. The "clean" newly moulted F-0 in June in Agadón, indicated in Fig. 6, and two in Perosín stream, shown in "other streams" in Table 6, support this. Possibly even some overwintering F-2 could join the emerging cohort as "clean" F-1 larvae were found already in late April (Fig. 6; Table 6) in the Frío and Águeda streams. Otherwise, on entering F-1 during summer, larvae evidently developed slower (many "dirty" larvae), delaying entry into F-0 until late summer (many "clean" F-0 larvae), and then entering a winter diapause. Thus, in a spring cohort split, the emerging cohort should have come from overwintering F-1 and F-0, and perhaps some overwintering F-2 larvae.

The "clean", newly moulted larvae occurred only in the period from April to October (Table 6), a time when water temperatures generally are above ca. $10^{\circ} \mathrm{C}$ (Fig. 2). "Dirty" F-1 larvae seemed to be present all year round, compatible with a slow summer development and reaching F-0 with a delay. "Clean" F-1 larvae may have peaked in early summer (mostly big specimens) and early autumn (6 small specimens), possibly with a minimum in August, although a F-2 exuvia (Fig. 6) indicated the presence of "clean" F-1 larvae at that time. A few clean early summer F-0 larvae, essentially at the beginning of the emergence period, indicate that they may have overwintered in F-1 and were shortly likely to emerge. A peak in "clean" F-0 in August-October indicates termination of a long-day diapause of F-1.

\section{DISCUSSION}

Voltinism is not easily determined in species that take several years to complete their larval development, because the inevitable overlap between size groups blurs the 
distinction between different year-class cohorts (Corbet, 1999). On the other hand, the phenomenon called "cohort splitting" (Norling, 1984) can enable some "outlier" members of a cohort to emerge either one year sooner (Corbet, 1957) or one year later than the rest of the cohort (Corbet et al., 2006). As a result of a cohort split, slow larvae spend an extra year (e.g., growth in three years) and overwinter as big larvae in an advanced stadium (F-1 or F-0), whereas fast larvae overwinter for the last time in an earlier stadium. When, in spring - early summer, the latter reach more advanced stadia, they are usually smaller (e.g. Norling, 1971), which is thought to be a consequence of a time stress (e.g., Stoks et al., 2008).

In the present study in the Sistema Central Mountains, western Spain, most Boyeria irene larvae develop in three years (partivoltinism) with a only a few developing faster and completing their development in two years (semivoltinism). Conversely, in the Sierra Morena Mountains, southern Spain, B. irene is mainly a semivoltine species (Ferreras-Romero, 1997), with only a few completing their development in three-years.

The reason for this difference is likely to be the temperature of the water, especially the minimum winter temperatures. In the Sistema Central Mountains growth apparently stops in late autumn during the period November-February, when water temperatures are always below $10^{\circ} \mathrm{C}$ (Fig. 2 ), when the number of F-1 and F-2 larvae, although low, was relatively constant (Table 2). However, in the warmer winters in the Sierra Morena Mountains, where the water temperature never dropped below $10^{\circ} \mathrm{C}$, growth continues slowly during the cool season, when in December ca. 50\% of the larvae were F-2 and 15\% F-1, but in February ca. 50\% were F-1 (Ferreras-Romero, 1997).

Eggs laid the previous summer hatch during May and June. This confirms the observation of Wenger (1963) that the first winter is spent in the egg stage. The young larvae-grow during summer and early autumn, and some are likely to reach F-2 before winter (Fig. 4). The time of emergence of this species extends until September in both the central and southern parts of the Iberian Peninsula (Ferreras-Romero \& Corbet, 1995). So, only in the period from May to June do larvae belonging to three consecutive hatching cohorts co-exist. Overwintering eggs and "summer species" characteristics (sensu Corbet, 1954, 1964) are common features of these populations.

Head-widths of F-2 and F-3 overlap, but wing-sheath lengths are discrete. This is also the case in the populations in the Sierra Morena Mountains (Ferreras-Romero, 1997). However, a reliable stadium assignment of small and middle sized larvae could be difficult or even impossible. Calculating the WSL/HW ratio, resulted in ranges and mean values that are similar to those reported by Tennessen (2017) for North American species, which is helpful. It is well known that Odonata, even within a population, vary in growth ratios recorded at moults and in the number of stadia required to complete development, and this may be both intrinsic and affected by diapause, food and time stress (e.g. Corbet, 2002). As proposed earlier, during au- tumn, the relatively big larvae assigned to F-4 (HW around $4.2 \mathrm{~mm}$ ) may develop as F-3 and, together with possibly unrecorded F-3, give rise to the small overwintering F-2 (Fig. 4). During the following spring and summer, these continue developing as the smallest F-1 and F-0.

The average growth ratio for the supposed two moults, from relatively big "F-4" (HW $4.1 \mathrm{~mm}$ ) to the relatively small springtime F-1 (HW $6.3 \mathrm{~mm}$ ) is 1.24 , which is a reasonable figure for fast development. If this is calculated over three moults the ratio is just 1.15, a low value, which may even indicate starvation or diapause (Corbet, 2002). For the extremes, $4.2 \mathrm{~mm}$ (biggest F-4) and $6.0 \mathrm{~mm}$ (smallest F-2), the average ratio for two moults is no more than 1.195, a not unusual value for older larvae. In western Spain (present study), these larvae are the semivoltine component of the population, with the possible addition in spring of a few fast growing overwintering larvae developing as F-3. All these larvae grow steadily and emerge throughout summer.

The small F-4 (HW 3.7-3.9 mm), and even smaller overwintering specimens, eventually undergo slow development during summer, probably due to long-day induced diapauses, which are postponing emergence and ultimately preparing for the next winter. These have smaller growth ratios and undergo one additional moult, mostly producing big overwintering F-1 (the average growth ratio for three moults from $3.9 \mathrm{~mm}$ to $6.7 \mathrm{~mm}$ is 1.20 ). This indicates that the critical size in spring associated with the cohort split separating those that emerge from the slower larvae is somewhere between a 4 and $5 \mathrm{~mm}$ head width (the "winter critical size" in Norling, 1984; Fig. 4). However, the emerging cohort is poorly represented in the samples, and the timing of the split is not well defined.

When many larvae reach F-2 to their first winter and some or most larvae overwintering in F-3 will emerge in summer, it would enable many larvae overwintering as F-3 and F-2 to develop in two years, a not uncommon pattern in aeshnids. This interpretation of the life cycle, shown in Fig. 4, is reminiscent of the life histories of Aeshna recorded in ponds in southern Sweden, e.g. A. viridis (Norling, 1971, 1984, Fig. 4). Like the $B$. irene populations, these species overwinter as eggs, and often have a mixed 2 or 3 year development, and a summer species pattern with a low frequency of overwintering F-0. However, their larval habitats and climatic conditions, with both higher and lower temperatures, are very different.

It is nevertheless interesting to compare it with $A$. viridis (Norling, 1971). In this species, the junior cohort could complete an additional stadium before winter than $B$. irene, with some reaching F-1, whereas most of the senior cohort, because of summer diapause, remained in F-1, during which cohorts merged (Norling, 1971, Fig. 5). In some years with slow growth the merging occurred in F-2 (Norling, 1971, Fig. 3), as apparently occurs in B. irene. In $A$. viridis the cohort split in spring roughly separated larvae overwintering in F-3 and bigger (accelerated semivoltine emerging cohort) from smaller larvae (delayed 3-year cohort). This is similar to that suggested here for $B$. irene. 
Our results support the conclusion that in the Sistema Central Mountains, in western Spain, Onychogomphus uncatus has a protracted, flexible larval development and a partivoltine life cycle. Larvae hatching from eggs laid in summer possibly segregate into "fast" and "slow" components, which complete development in three and four years, respectively, and pass their last winter in mainly the two last stadia, in particular F-0. The number of larvae with a three-year development may be low. Unlike what seems to happen in the Sierra Morena Mountains, in southern Spain (Ferreras-Romero et al., 1999), semivoltinism appears not to exist in these $O$. uncatus populations. Although the emergence period may change from one year to another, according to our records (Fig. 6) it begins in the second half of June, apparently with a peak, and extends sporadically until the beginning of September.

This species is reported not to undergo an embryonic diapause and in the field (southern France) eggs start developing as soon as laid and hatch during the second half of summer, about four weeks after being laid with no evidence of egg overwintering except that oviposition was observed so late that the temperature then would have prevented hatching (Schütte et al., 1998). According to Schütte et al. (1998), hatchlings in France have a head width of around $0.4 \mathrm{~mm}$. In the present study, the larval recruitment period peaked in August-September, but hatchlings were present from July to late November, indicating a drawn out recruitment correlating with the few adults emerging late.

The smallest recorded winter larva (HW ca. $0.45 \mathrm{~mm}$ ) should have moulted no more than once. In June and early July there were still single larvae of this size, and in late July, there were also single larvae in this and the following stadium (ca. $0.55 \mathrm{~mm}$ ). These were certainly not from the same season's oviposition, in late July the first distinct stadium peak of those that hatched the previous season, which had HWs of between 0.6 and $0.7 \mathrm{~mm}$ (Fig. 7). Therefore, a few eggs may have overwintered and hatched in spring, as suspected by Schütte et al. (1998). This can be seen as a continuation of a late autumn hatching. Facultative egg overwintering is reported for the gomphids Gomphus flavipes and Ophiogomphus cecilia (Schütte, 1998; Wildermuth \& Martens, 2014).

Growth is very slow during the first autumn, and the first winter is spent in very early stadia, after 1 to 3 moults (Fig. $7)$. Due to low water temperatures in winter, the size range in early spring is identical (Fig. 6). Similar slow first year growth is also recorded in the Sierra Morena Mountains (Ferreras-Romero et al., 1999).

In the second year of growth cohorts become indistinct. After the spring-autumn growth, HW in the second winter appeared to range between 1.0 and $3.0 \mathrm{~mm}(\mathrm{~F}-3)$, but the larvae with HWs above $2 \mathrm{~mm}$ seem doubtful, and would require an extremely high growth rate in early summer, which is contrary to their otherwise slow growth. This seems to require 3-4 moults between May and July. However, in warmer southern Spain such increases in the rate of development seem to occur in March-April, followed by a relative stasis (Ferreras-Romero et al., 1999). Since the present samples were collected at several sites, a variation in growth rate is likely, but speculative.

During the third year of growth, cohort separation is not possible. Larvae that had HWs of ca. 1 and $2 \mathrm{~mm}$ after their second winter (slow component), mostly reached F-4 to F-2 stadia. The fused peak of F-4 and F-3, containing the bulk of these larvae, is remarkable. It is well separated from both F-2 and smaller larvae, but F-4 and F-3 are not separated. The separation is so narrow that all F-4 except the smallest ( $2.5 \mathrm{~mm}$ and above) would, with a more normal (Corbet, 2002) growth ratio of 1.23 , reach the size of F-2 after moulting. Although it is not discernible in the scattered data, it may be a peak with a common history, approximately corresponding to the F-3 of Schütte et al. (1998). It may later develop with different numbers of moults. This must happen when the number of stadia is not constant. A minimum of $2.3 \mathrm{~mm}$ might argue for this scenario, perhaps harking back to a separation between agecohorts. If the larvae that overwinter as F-4 and F-3 are in their third winter, they will mostly develop in 4 years, spending the last winter in F-1 or F-0. If it is their second winter, which seems unlikely, they make it in three years.

In the following spring, larvae in F-4/F-3, irrespective of their age, seemed to be involved in a cohort split. Larvae that probably passed the winter in F-4/F-3 grew slowly during summer, undergoing weak long-day diapauses, and finally reached F-0 during the shorter late-season photoperiods (Norling, 1984; Corbet, 1999). Some F-2 larvae in May and June may have moulted directly from big larvae assigned to F-4. At the same time a gap formed in the size range of F-3, the putative cohort split, but later a frequency gap was not evident in the small samples. However, in southern France, Schütte et al. (1998), in a population developing mainly in three years, found consistent winter frequency peaks in F-3 (penultimate winter) and F-0, and a minimum in F-2 (final winter) due to a cohort split. This type of split anticipates the spring cohort split before winter, and is typical for early-flying species (Norling, 1984), but might not have been distinct in the slower growing population studied.

The subsequent fate of the overwintering F-2 larvae is uncertain. Some of these larvae probably enter F-0 and overwintered in diapause after delayed development, whereas other overwintering F-2 larvae might join the emerging cohort of that summer, as they do in southern France (Schütte et al., 1998), if they reach F-1 early, as can happen in April (Fig. 6). This cohort split above or within F-2 separates emerging and overwintering cohorts, but the split here is largely invisible due to the paucity of data, except perhaps for a gap in the occurrence of F-0.

So, the emerging cohort consists of larvae that spent the previous winter in the two last stadia, and possibly some in F-2. Higher numbers of F-0 than F-1 larvae during autumn and winter (late October to early April), and a probable early peak in emergence, are "spring species" (sensu Corbet, 1964) characteristics of this population. However, the possible contribution of some overwintering F-2, and some rather late emerging specimens, are summer species 
characteristics. Populations of this species are best characterized as an intermediate, transitional type (Paulson \& Jenner, 1971; Ferreras-Romero et al., 1999). According to the two-step photoperiodic reaction demonstrated in many temperate zone dragonflies, this means that in spring, larvae that are above the critical size (here F-1 and perhaps some F-2) accelerate their development in long days, and proceed to emergence. Larvae starting below this size finally, often when reaching F-2 or bigger, undergo diapause of variable intensity in response to long days, a diapause which is usually terminated by the short late-season days, when a short-day diapause is induced. This is also true of the $B$. irene population studied here.

In the study of Schütte et al. (1998), the spring-summer species characteristics are also ambiguous. In the three last stadia, where the winter before emergence was spent, there was a distinct peak in F-0 in the winter samples $(50 \%$ or more of the last-winter larvae), and the lowest number in F-2, forming a winter minimum, probably due to an early cohort split. This can be expected to produce a spring species type of emergence, but ending somewhat late. However, for three years, there was a typical summer species emergence profile from this river, which remains to be explained, but this species emerged in a spring-species fashion from an adjacent river, where environmental conditions probably enabled more of the larvae to complete their development to F-0 before emergence. This may suggest that all these populations are intermediate in their characteristics. Emergence can take place from larvae overwintering in the two or three last stadia, but weak regulatory responses before the final stadium simultaneously seems to allow a frequency peak in $\mathrm{F}-0$, and often a spring species profile.

In $B$. irene, and many other more typical summer species, emergence is from larvae that overwintered in one of the three or four last stadia, and strong regulatory responses in summer can counteract an F-0 peak (e.g. some Aeshna species; Norling, 1971; Corbet, 1999) and prevent an early emergence peak.

This study confirms that the common practice of assigning field collected larvae to particular stadia, especially those smaller than the two or three last stadia, is difficult. For example, the interpretation of larval development in $B$. irene requires a leap from apparent $\mathrm{F}-4$ to the $\mathrm{F}-2$ stadium. Evidence is also provided of how voltinism and larval growth differ in different environmental conditions on the Iberian Peninsula, in particular at sites with different winter water temperatures. Finally, whereas $B$. irene has a typical aeshnid summer species pattern of development and phenology, $O$. uncatus seems to bridge the gap between a spring and summer species by means of a gradual transition, as proposed by Pauson \& Jenner (1971).

\section{REFERENCES}

Askew R.R. 2004: The Dragonflies of Europe. Harley Books, Colchester, $308 \mathrm{pp}$.

Boudot J.P. \& Dommanget J.L. 2015: Onychogomphus uncatus. In Boudot J.P. \& Dommanget J.L. (eds): Atlas of the European Dragonflies and Damselflies. KNNV, Zeist, pp. 205-206.
Boudot J.-P., Kalkman V.J., Azpilicueta Amorin M., Bogdanovic T., Cordero Rivera A., Degabriele G., Dommanget J.L., Ferreira S., Garrigos B., Jovic M. et al. 2009: Atlas of the Odonata of the Mediterranean and North Africa. - Libellula (Suppl.) 9: $256 \mathrm{pp}$.

Boudot J.P., Lockwood M. \& Cordero Rivera A. 2015: Boyeria irene. In Boudot J.P. \& Dommanget J.L. (eds): Atlas of the European Dragonflies and Damselflies, KNNV, Zeist, p. 181.

Campos F., Velasco T., Sánchez G. \& Santos E. 2013: Odonatos de la cuenca alta del río Águeda (Salamanca, oeste de España) (Insecta: Odonata). - Bol. Soc. Entomol. Aragon. 53: 234-238.

Clausnitzer H.J., Hengst R., Krieger C. \& Thomes A. 2010: Boyeria irene in Niedersachsen (Odonata: Aeshnidae). $-\mathrm{Li}$ bellula 29: 155-168.

Confederación Hidrográfica del Duero 2018: Visor Mírame. URL: http://www.mirame.chduero.es (last accessed 31 Jul. 2018).

CORBEt P.S. 1954: Seasonal regulation in British dragonflies. Nature 174: 655.

CORBET P.S. 1957: The life-history of the emperor dragonfly Anax imperator Leach (Odonata: Aeshnidae). - J. Anim. Ecol. 26: $1-69$.

CORBET P.S. 1964: Temporal patterns of emergence in aquatic insects. - Can. Entomol. 96: 264-279.

Corbet P.S. 1999: Dragonflies: Behaviour and Ecology of Odonata. Harley, Colchester, 829 pp.

CORBET P.S. 2002: Stadia and growth ratios of Odonata: a review. - Int. J. Odonatol. 5: 45-73.

Corbet P.S., Suhling F. \& Soendgerath D. 2006: Voltinism of Odonata: a review. - Int. J. Odonatol. 9: 1-44.

FERRERAS-Romero M. 1997: The life history of Boyeria irene (Fonscolombe, 1838) (Odonata: Aeshnidae) in Sierra Morena Mountains (southern Spain). - Hydrobiologia 345: 109-116.

Ferreras-Romero M. 1999: Biodiversity of rheophilous Odonata in southern Spain. - Odonatologica 28: 417-420.

Ferreras-Romero M. \& Corbet P.S. 1995: Seasonal patterns of emergence in Odonata of a permanent stream in southwestern Europe. - Aquat. Insects 17: 123-127.

Ferreras-Romero M. \& Corbet P.S. 1999: The life cycle of Cordulegaster boltonii (Donovan, 1807) (Odonata: Cordulegastridae) in the Sierra Morena Mountains (southern Spain). - Hydrobiologia 405: 39-48.

Ferreras-Romero M., Atienzar M.D. \& Corbet P.S. 1999: The life cycle of Onychogomphus uncatus (Charpentier, 1840) (Odonata: Gomphidae) in the Sierra Morena Mountains (southern Spain): an example of protracted larval development in the Mediterranean basin. - Arch. Hydrobiol. 144: 215-228.

JunTA DE CASTILla y León 2018: Visor de Información Geográfica. URL: http://www.idecyl.jcyl.es/hac/6/VCIG/Login.ini (last accessed 31 Jul. 2018).

JurzitzA G. 1967: Ein beitrag zur kenntnis der Boyeria irene (Fonscolombe), (Odonata, Aeshnidae). - Beitr. Naturk. Forsch. SüdwDtl. 26: 149-154.

LARSON D.J. 1985: Structure in temperate predaceous diving beetle communities (Coleoptera: Dytiscidae). - Ecography 8: $18-32$.

Miller A.K. \& Miller P.L. 1985: Simultaneous occurrence of crepuscular feeding and sexual activity in Boyeria irene (Fonsc.) in southern France (Odonata, Aeshnidae). - Entomol. Mon. Mag. 121: 123-124.

Norling U. 1971: The life history and seasonal regulation of Aeshna viridis Eversm. in southern Sweden (Odonata). - Insect Syst. Evol. 2: 170-190. 
NoRLING U. 1976: Seasonal regulation in Leucorrhinia dubia (Vander Linden) (Anisoptera: Libellulidae). - Odonatologica 5: $245-263$.

NORLING U. 1984: Life history patterns in the northern expansion of dragonflies. - Adv. Odonatol. 2: 127-156.

Paulson D.R. \& Jenner C.E. 1971: Population structure in overwintering larval Odonata in North Carolina in relation to adult flight season. - Ecology 52: 96-107.

Reguera de Castro J.M. \& Ramírez-Estévez G. 1995: Atlas del territorio de Castilla y León. Junta de Castilla y León, Consejería de Medio Ambiente y Ordenación del Territorio, Valladolid, $144 \mathrm{pp}$.

Rivas-Martínez S. 1987: Memoria del mapa de Series de vegetación de España 1:400.000. ICONA. Ministerio de Agricultura Pesca y Alimentación. Madrid.

Robert P.-A. 1958: Les Libellules (Odonates). Delachaux \& Niestlé, Neuchâtel, 364 pp.

SCHÜTTE C. 1998: Überwinterung der Eier von Gomphus flavipes (Charpentier) und Ophiogomphus cecilia (Fourcroy) (Anisoptera: Gomphidae). — Libellula 17: 59-70.

SchütTe C., Schridde P. \& Suhling F. 1998: Life history patterns of Onychogomphus uncatus (Charpentier) (Anisoptera: Gomphidae). - Odonatologica 27: 71-86.

Stoks R., Johansson F. \& De Block M. 2008: Life history plasticity under time stress in damselfly larvae. In Cordoba-Aguilar A. (ed.): Dragonflies: Model Organisms for Ecological and
Evolutionary Research. Oxford University Press, Oxford, pp. 39-51.

SuHLING F. 1995: Temporal patterns of emergence of the riverine dragonfly Onychogomphus uncatus (Odonata: Gomphidae). Hydrobiologia 302: 113-118.

SuHLING F. \& Müller O. 1996: Die Flussjungfern Europas. 2. Gomphidae. Spektrum, Heidelberg, $240 \mathrm{pp}$.

Sutherland W. 2006: Ecological Census Techniques. Cambridge University Press, Cambridge, 432 pp.

TENNESSEn K. 2017: A method for determining stadium number of late dtage dragonfly nymphs (Odonata: Anisoptera). - Entomol. News 126: 299-306.

THOMPsOn D.J. 1978: Towards a realistic predator-prey model: the effect of temperature on the functional response and life history of larvae of the damselfly, Ischnura elegans. - J. Anim. Ecol. 47: 757-767.

Wenger O.P. 1955: Ist Boyeria irene Fonsc. ein Dämmerungsflieger? (Odonata, Aeschnidae). — Mitt. Schweiz. Entomol. Ges. 28: 279-280.

WeNGER O.P. 1963: Libellenbeobachtungen in Südfrankreich und Spanien (Odonata). - Mitt. Schweiz. Entomol. Ges. 35: 255-269.

WiLDERMUTH H. \& MARTENS A. 2014: Taschenlexikon der Libellen Europas. Quelle \& Meyer, Wiebelsheim, 824 pp.

Received May 28, 2018; revised and accepted September 8, 2018 Published online December 12, 2018 